ISSN 0258-7122 (Print), 2408-8293 (Online)

Bangladesh J. Agril. Res. 43(1): 109-123, March 2018

\title{
THE POLICY ANALYSIS MATRIX OF PULSE CROPS PRODUCTION IN BANGLADESH
}

\author{
M. A. RASHID ${ }^{1}$ AND M. A. MATIN ${ }^{2}$
}

\begin{abstract}
This study examined the relative efficiency of producing of selected pulse crops in Bangladesh and their comparative advantage in international trade. To know the comparative advantage in production of selected pulse crops. The study have calculated net financial and economic profitability, nominal protection coefficient of output (NPCO), nominal protection coefficient of input (NPCI), effective protection co-efficient (EPC), private cost ratio (PCR), policy analysis matrix (PAM) and domestic resource cost (DRC). Data used in this study were collected through Household surveys from 300 sample farms located in 12 villages under 6 districts in Bangladesh for the period 2015 to 2016. The selected pulse crops i.e lentil, chickpea and mungbean cultivation at farm level is very much remunerative to its growers. The domestic-border price ratio of selected pulse crops indicates that domestic pulse production was taxed and consumers were subsidized. The border price of selected pulse crops at producer level was mostly higher than the domestic producer price indicating that there is a wide scope to cultivate pulse crops for import substitution in Bangladesh. Policy Analysis Matrix for selected pulse crops under import parity prices showed that revenue transfer ( $\mathrm{Tk}-14,755 / \mathrm{mt}$ ) was negative indicated that government policies affect negatively to the pulse producer. The input transfer (Tk $-1108 / \mathrm{mt}$ ) was also negative indicating that the government has implemented input subsidy policy to the crop sector to offset higher cost of production. The domestic factor transfer was positive (Tk 15,171/mt) indicating that opportunity costs of non-tradable inputs were lower than their market prices. Finally the net profit/net policy transfer (Tk -28,503/mt) was negative which means that, the producers earn less profit and cannot minimize loss under existing condition and vice-versa. This means that under free trade, producers could make more profit in contrast to the existing policy environment. The NPCO values less than one imply that policies do not provide nominal protection for the pulse producers. The findings based on the indicators of NPCO, NPCI, EPC and PCR conclude that the existing government policy environment tends to protect the interest of the pulse producers in agricultural sector at production level. DRC results indicated that Bangladesh had comparative advantage of producing pulse crops and production of pulse crops would be highly efficient for import substitution.
\end{abstract}

Keywords: Nominal protection coefficient (NPC), Effective protection coefficient (EPC), Policy analysis matrix (PAM), Domestic resource cost (DRC), Profitability, Pulse crops, Bangladesh.

${ }^{1}$ Principal Scientific Officer, ${ }^{2}$ Chief Scientific Officer, Agricultural Economics Division, Bangladesh Agricultural Research Institute (BARI), Gazipur, Bangladesh. 


\section{Introduction}

Bangladesh is one of the major potential pulse growing countries of the world, but it has not yet been able to attain self-sufficiency in pulse production. Besides, the high population growth in Bangladesh causes pulse deficiency in this country. Bangladesh had to import pulse every year to meet this deficit. Continued imports of pulse should neither be encouraged nor accepted as the right way for meeting the pulse deficit, since Bangladesh has the capacity to increase pulse production to a substantial extent. Internal production not only saves foreign exchange but also keeps the production machinery viable and strong to face the vagaries of nature, helps in employment generation and makes the country selfreliant. The government policy in this respect is the most important catalyst. Bangladesh is a densely populated country where per capita cultivable land availability is not more than 0.066 ha. It has been projected that per capita land availability may come down to 0.061 ha by the year 2010 and 0.053 ha by 2020 . Farmer is not likely to come forward with a risky crop because harvest risky. The country is facing acute shortage of pulses due to accelerated increase of requirements with its rapid growth of population. Side by side the fallow period between two major crops to be utilized for production of pulse crops. Pulses area decreased from 7.35 lakh hectares in 1988-89 to 3.57 lakh hectares in 2014-15 (BBS, 2015). Production also decreased from 5.12 lakh tonnes to 3.79lakh tonnes during the same period (Table.1.1). The average yield of pulse was $1.25 \mathrm{mt} / \mathrm{ha}$. The area and production were decreased due to increase of the area for boro rice and other high value crops. Food and Agricultural Organization (FAO) recommended consumption of pulse amounting $45 \mathrm{gm} / \mathrm{head} /$ day for fulfilling protein requirements for an adult. Presently per capita availability of pulses in Bangladesh is about $17 \mathrm{gm}$, which is far below the actual requirement. Under this situation, more thrust should be given in developing technologies relating to pulses crops so that the farmer feels secured about the crops.

Import substitute of pulse crops would determine the position of the Bangladeshi cultivators in respect of production of this commodity by using scarce resources. Again, the trading opportunities of the country's products depend on the comparative advantage, without subsidies or with limited subsidies that are permitted for all trading partners by the rules governing the new trading environment. All these information would be of much help to the planners and policy-makers in formulating appropriate policies for optimum and efficient resource allocation within agriculture and between agriculture and nonagricultural sectors, consistent with a balanced and integrated development of Bangladesh economy. In order to formulate an appropriate policy for import substituting, so the present study was undertaken to highlight the economic performance as well as comparative advantage of pulse crops cultivation in Bangladesh. 
Table 1.1. Area, production and yield of pulses in Bangladesh

\begin{tabular}{|c|c|c|c|}
\hline Year & Area (ha) & Production (mt) & Yield (t/ha) \\
\hline $1988-89$ & 735448 & 495548 & 1.48 \\
\hline $1989-90$ & 738053 & 512210 & 1.44 \\
\hline $1990-91$ & 728395 & 523060 & 1.39 \\
\hline 1991-92 & 721893 & 519155 & 1.39 \\
\hline $1992-93$ & 713231 & 516905 & 1.38 \\
\hline 1993-94 & 709391 & 530455 & 1.34 \\
\hline $1994-95$ & 710504 & 533640 & 1.33 \\
\hline $1995-96$ & 696905 & 523930 & 1.33 \\
\hline $1996-97$ & 687607 & 523490 & 1.31 \\
\hline $1997-98$ & 682817 & 517515 & 1.32 \\
\hline 1998-99 & 546883 & 417375 & 1.31 \\
\hline 1999-00 & 497692 & 383030 & 1.30 \\
\hline $2000-01$ & 474595 & 365410 & 1.30 \\
\hline 2001-02 & 451996 & 342490 & 1.32 \\
\hline $2002-03$ & 448415 & 349140 & 1.28 \\
\hline 2003-04 & 420933 & 332890 & 1.26 \\
\hline $2004-05$ & 383306 & 316080 & 1.21 \\
\hline $2005-06$ & 337368 & 279420 & 1.21 \\
\hline 2006-07 & 311352 & 257505 & 1.21 \\
\hline $2007-08$ & 225712 & 203535 & 1.11 \\
\hline 2008-09 & 226484 & 196071 & 1.16 \\
\hline $2009-10$ & 242261 & 220486 & 1.10 \\
\hline 2010-11 & 253898 & 232127 & 1.09 \\
\hline 2011-12 & 269636 & 238000 & 1.13 \\
\hline $2012-13$ & 283806 & 265000 & 1.07 \\
\hline 2013-14 & 333198 & 352000 & 0.95 \\
\hline $2014-15$ & 357490 & 379000 & 0.94 \\
\hline
\end{tabular}

Source: BBS (1992), BBS (1997), BBS (2004), BBS (2008), BBS (2012), BBS (2015).

\section{Objectives of the study}

i. To estimate the financial and economic profitability of pulse cultivation,

ii To assess the import substitution status of major pulse crops,

iii To drive the policy implications from the above. 


\section{Materials and Methods}

\subsection{Selection of Samples}

The pulses growing farmers were considered as the population for this study. Keeping in view the objectives and time constraint of the study, altogether 300 sample taking 50 from each crop and each location. The study areas were purposively selected based on intensive pulse growing pockets in Bangladesh. The distribution of crops and their respective locations and sample size are shown in Table 2.1.

Table 2.1. Crops and locations wise sample size of selected pulse crops

\begin{tabular}{l|c|c}
\hline Name of the crops & Study locations & Sample size \\
\hline Lentil & Natore and Jessore & 100 \\
Chickpea & Rajshahi and Natore & 100 \\
Mungbean & Rajshahi and Jessore & 100 \\
Total & & $\mathbf{3 0 0}$ \\
\hline
\end{tabular}

The study also required official exchange rate (Tk/USD), public transport freight rate $(\mathrm{Tk} / \mathrm{ton} / \mathrm{Km})$, 0cean freight rate, commodity prices at international market, commodity prices at domestic market, fertilizer prices at international market etc. which have been collected from different published and unpublished sources.

\subsection{Analytical Technique}

Both financial and economic profitability of the selected pulse crops have been estimated to fulfill the study objectives.

\subsubsection{Measurement of financial profitability}

In this study for financial profitability estimation, costs and returns analyses were done on both variable and total cost basis. The following equation (П) was developed to assess the financial profitability of cultivating pulse crops in Bangladesh.

$$
\Pi_{\mathrm{i}}=\sum_{i=1}^{n} \mathrm{P}_{\mathrm{i}} \mathrm{Q}_{\mathrm{i}}-\mathrm{TC}=\sum_{i=1}^{n} \mathrm{P}_{\mathrm{i}} \mathrm{Q}_{\mathrm{i}}-(\mathrm{VC}+\mathrm{FC})
$$

Where,

$\Pi_{\mathrm{i}}=$ Profit or value addition from $\mathrm{i}^{\text {th }}$ pulse crop production

$\mathrm{Q}_{\mathrm{i}}=$ Quantity of the $\mathrm{i}^{\mathrm{th}}$ product $(\mathrm{kg} / \mathrm{ha})$

$\mathrm{P}_{\mathrm{i}}=$ Average price of $\mathrm{i}^{\text {th }}$ product $(\mathrm{Tk} / \mathrm{kg})$

$\mathrm{TC}=$ Total cost $(\mathrm{Tk} / \mathrm{ha})$

$\mathrm{VC}=$ Variable cost $(\mathrm{Tk} / \mathrm{ha})$

$\mathrm{FC}=$ Fixed cost $(\mathrm{Tk} / \mathrm{ha})$

$\mathrm{i}=1,2,3, \ldots \ldots \ldots, \mathrm{n}$ 
Per hectare profitability of growing pulse crops from the view points of individual farmers was measured in terms of gross return, gross margin and net return.

Gross return: Gross return was calculated by simply multiplying the total volume of output with it's per unit price in the harvesting period.

Gross margin: Gross margin is the difference between total return and variable costs. The argument for using the gross margin analysis is that the farmers of Bangladesh are more interested to know their return over variable costs.

Net return: The analysis considered fixed cost which included land rent and family supplied labour. Net margin was calculated by deducting total costs (Variable and Fixed) from gross return.

\subsubsection{Policy Analysis Matrix (PAM) framework}

Policy Analysis Matrix (PAM) framework was used to measure competitiveness, economic efficiency and effects of policy interventions of the pulse crops. This framework was developed first by Monke and Pearson (1989), and augmented by recent developments in price distortion analysis by Masters and Winter-Nelson (1995). PAM is a tool that allows to examine the impact of policy by constructing two enterprise budgets, one valued at market prices and the other valued at social prices. The PAM, once assembled, provides a convenient method of calculating the measure of policy effects and measures of competitiveness and economic efficiency/ comparative advantage. This framework is particularly useful in identifying the appropriate direction of change in policy (Gonzales et $a l ., 1993)$. In the present study, particular attention is given to competitiveness and economic efficiency in domestic resources by using a PAM framework. The assessment of competitiveness and economic efficiency of pulse crops production at the farmgate level in different locations of Bangladesh were undertaken and the necessary indicators were derived to explain the private profitability, social profitability and divergence.

Table 2.2. Framework of Policy Analysis Matrix (PAM)

\begin{tabular}{l|c|c|c|c}
\hline \multirow{2}{*}{ Items } & \multirow{2}{*}{ Revenue } & \multicolumn{2}{|c|}{ Costs } & \\
\cline { 3 - 4 } & & Tradable inputs & Domestic factors & Profit \\
\hline Private prices & A & B & C & D \\
Social prices & E & F & G & H \\
Divergences & I & J & K & L \\
\hline
\end{tabular}

Source: Monke and Pearson (1989).

Private profit $(\mathrm{D})=\mathrm{A}-(\mathrm{B}+\mathrm{C})$, Social profit $(\mathrm{H})=\mathrm{E}-(\mathrm{F}+\mathrm{G})$, Output transfer $(\mathrm{I})=\mathrm{A}-\mathrm{E}$, Input transfer $(\mathrm{J})=\mathrm{B}-\mathrm{F}$, Factor transfer $(\mathrm{K})=\mathrm{C}-\mathrm{G}$, Net transfer $(\mathrm{L})=\mathrm{D}-\mathrm{H}$ or I-J-K

Valued at Private prices $\mathrm{A}=P i d * Q i, \quad \mathrm{~B}=P j d * Q j, \quad \mathrm{C}=$ Pnd $* Q n \mathrm{D}$ 
Valued at Social prices E $=P i b * Q i$,

$\mathrm{F}=P j b^{*} Q j$

$\mathrm{G}=P n s * Q n \mathrm{H}$

Where: Pid $=$ domestic price of output $i$

Pjd $=$ domestic price of tradable input $j$

$P i b=$ international price of output $i$

$P j b=$ international price of tradable input $j$

Pnd $=$ market price of non-tradable input $n$

Pns $=$ shadow price of non-tradable input $n$

$Q i=$ quantity of output

$Q j=$ quantity of tradable input.

$Q n=$ quantity of non-tradable input.

The indicators in the first row of Table 2.1 provide a measure of private profitability (D), or competitiveness, and are defined as the difference between observed revenue $(A)$ and costs $(B+C)$. Private profitability demonstrates the competitiveness of the agricultural system, given current technologies, prices for inputs and outputs, and policy interventions and market failures. The second row of the matrix calculates the measure of social profitability $(\mathrm{H})$ defined as the difference between social revenue $(\mathrm{E})$ and costs $(\mathrm{F}+\mathrm{G})$. Social profitability measures economic efficiency/ comparative advantage of the agricultural system.

\subsubsection{Ratio indicators}

The PAM framework can also be used to calculate important indicators for policy analysis. The computations of the following measures are established based on Appleyard (1987).

\section{a) Nominal Protection Coefficient on Output (NPCO)}

This ratio shows that the extent to which domestic prices of output differ from international reference prices. If NPCO is greater than one, the domestic farm gate price is greater than the international price of output and thus the system receives protection. On the contrary, if NPCO is less than one, the system is disprotected by policy. NPCO is expressed as:

$\mathrm{NPCO}=(\mathrm{A}) /(\mathrm{E})=(\mathrm{Pid} * \mathrm{Qi}) /(\mathrm{Pib} * \mathrm{Qi})$

\section{b) Nominal Protection Coefficient on Input (NPCI)}

This ratio shows how much domestic prices for tradable inputs differ from their social prices. If NPCI exceeds one, the domestic input cost is greater than the comparable world prices and thus the system is taxed by policy. If NPCI is less than one, the system is subsidized by policy. Using the PAM framework, NPCI is derived as:

$\mathrm{NPCI}=(\mathrm{B}) /(\mathrm{F})=(\mathrm{Pjd} * \mathrm{Qj}) /(\mathrm{Pjb} * \mathrm{Qj})$ 


\section{c) Effective Protection Coefficient (EPC)}

EPC is the ratio of value added in private prices (A-B) to value added in social prices (E-F). An EPC value of greater than one suggests that government policy protects the producers, while values less than one indicate that producers are disprotected through policy interventions. EPC is expressed as:

$\mathrm{EPC}=(\mathrm{A}-\mathrm{B}) /(\mathrm{E}-\mathrm{F})=\{(\mathrm{Pid} * \mathrm{Qi})-(\mathrm{Pjd} * \mathrm{Qj})\} /\{(\mathrm{Pib} * \mathrm{Qi})-(\mathrm{Pjb} * \mathrm{Qj})\}$

\section{d) Domestic Resource Cost (DRC)}

The DRC is the ratio of the cost in domestic resources and non-traded inputs (valued at their shadow prices) of producing the commodity domestically to the net foreign exchange earned or saved by producing the good domestically.

Formally DRC is defined as:

$\mathrm{DRC}=\frac{\text { Cost of domesticresource and non }- \text { tradedinputsfor producing per unit of output }}{\text { Value of tradableoutput }- \text { Value of tradableinputs }}$

$$
\text { Or, DRC }=\frac{\sum \mathrm{f}_{\mathrm{ij}} \mathrm{p}_{\mathrm{j}} \mathrm{d}}{\mathrm{U}_{\mathrm{i}}-\sum \mathrm{a}_{\mathrm{ik}} \mathrm{p}_{\mathrm{k}}^{\mathrm{b}}}
$$

Where,

$\mathrm{f}_{\mathrm{ij}}=$ Domestic resource and non-traded inputs $\mathrm{j}$ used for producing per unit commodity i

$\mathrm{P}_{\mathrm{j}}^{\mathrm{d}}=$ Price of non-traded intermediate inputs and domestic resource

$\mathrm{U}_{\mathrm{i}}=$ Border price of output $\mathrm{i}$

$\mathrm{a}_{\mathrm{ik}}=$ Amount of traded intermediate inputs for unit production of $\mathrm{i}$

$\mathrm{P}^{\mathrm{b}}{ }_{\mathrm{k}}=$ Border price of traded intermediate input

If $\mathrm{DRC}<1$, the economy saves foreign exchange by producing the good domestically either for export or for imports substitution. This is because the opportunity cost of domestic resources and non-traded factors used in producing the good is less than the foreign exchange earned or saved. In contrast, if DRC > 1 , domestic costs are in excess of foreign exchange costs or savings, indicating that the good should not be produced domestically and should be imported instead.

\section{e) Private Cost Ratio (PCR)}

PCR is the ratio of factor costs $(\mathrm{C})$ to value added in private prices (A-B). This ratio measures the competitiveness of a commodity system at the farm level. The system is competitive if the PCR is less than one. Using the PAM framework the PCR can be expressed as:

$\mathrm{PCR}=(\mathrm{C}) /(\mathrm{A}-\mathrm{B})=(\mathrm{Pnd} * \mathrm{Qn}) /\{(\mathrm{Pid} * \mathrm{Qi})-(\mathrm{Pjd} * \mathrm{Qj})\}$ 


\subsubsection{Import Parity Analysis}

The estimates of world price at import parity level are based on the assumption that imports compete with domestic production at the producer level. The border prices of selected commodities have been adjusted for marketing cost (which includes handling, transportation, storage cost) and price spent between the wholesale market to the farmers level. Border prices of commodities are used as reference or shadow prices in measuring the effects of government intervention polices. Without government intervention, the domestic producer prices are expected to be closely related to the border prices.

Import parity: Import parity price at farm level is estimated using the following formulae

$$
P_{j}=P_{j}^{b}+C_{j m}-C_{j d}
$$

Where,

$P_{j}=$ Producer price of $j^{\text {th }}$ importable commodity,

$\mathrm{P}_{\mathrm{j}}^{\mathrm{b}}=$ World price at port of entry (c.i.f),

$\mathrm{C}_{\mathrm{jm}}=$ Marketing margin from the port of entry to the wholesale market and

$\mathrm{C}_{\mathrm{jd}}=$ Components of the marketing spread between the wholesale market and farm gate.

\subsubsection{Shadow Pricing of Inputs for PAM Analysis}

Land - Rental value of per unit of land is applied for calculating the shadow price of land

$>$ Labor - Market wage rate is considered for shadow pricing because no substantial market imperfection exists in agricultural labor market

$>$ Working capital - Interest rate for working capital

$>$ Fertilizers-International prices are used to calculate the import parity prices

$>$ Seed - Actual market price

\section{Results and Discussion}

\subsection{Pattern of Input Use for Selected Pulses Cultivation}

Farmers employed different level of inputs for pulse cultivation. An attempt was made to estimate the level of inputs used and benefits obtained by the farmers of selected pulses. On an average, farmers applied Urea at the rate of $33 \mathrm{~kg} / \mathrm{ha}$, TSP $66 \mathrm{~kg} / \mathrm{ha}$, and MoP $39 \mathrm{~kg} / \mathrm{ha}$ for lentil cultivation, whereas it was $40 \mathrm{~kg} / \mathrm{ha}, 63$ $\mathrm{kg} / \mathrm{ha}$ and $54 \mathrm{~kg} / \mathrm{ha}$ for mungbean cultivation respectively. For chickpea cultivation, farmers were applied only Urea (32 kg/ha), DAP (72 kg/ha) and 
Boron $(7 \mathrm{~kg} / \mathrm{ha})$ in the study areas. It was observed that among the selected pulses, farmers used Urea and MoP common in the study areas (Table 3.1). They employed on an average 113 man-days per hectare of total human labour (both family \& hired) for lentil cultivation, which was 96 man-days for chickpea cultivation and 150 man-days for mungbean cultivation. Respondent applied pesticides once a season and no weeding and irrigation were applied for selected pulses cultivation.

Table 3.1. Per hectare use of input in producing selected pulses

\begin{tabular}{l|c|c|c}
\hline \multirow{2}{*}{\multicolumn{1}{c}{ Items }} & \multicolumn{3}{c}{ Selected pulses } \\
\cline { 2 - 4 } & Lentil & Chickpea & Mungbean \\
\hline Hired labour (man-days) & 77 & 57 & 85 \\
Family labour(man-days) & 36 & 39 & 65 \\
Total human labour (man-days) & 113 & 96 & 150 \\
Mechanical power (Tk/ha) & 4869 & 4491 & 4603 \\
Fertilizers (kg): & & & \\
Urea & 33 & 32 & 40 \\
TSP & 66 & - & 63 \\
MoP & 39 & - & 54 \\
DAP & - & 72 & - \\
Boron & - & 7 & - \\
Seed (Kg) & 56 & 60 & 23 \\
Insecticide (Tk) & 676 & 1404 & 1415 \\
\hline
\end{tabular}

\subsection{Yield performance}

The average yield of lentil, chickpea and mungbean were 2.0 tons, 1.6 tons and 1.7 tons fresh yield per hectare respectively in the study areas (Table 3.2). In all study districts farmers produced the highest yield in Jessore district (2.1 tons/ha) in respect of lentil compared to mungbean (1.8 tons/ha) in same district. In the case of chickpea production the higher yield was recorded in Rajshahi district (1.6 tons/ha) compared to Natore district (1.5 tons/ha).

Table 3.2. Yield of lentil, chickpea and mungbean under studied districts

(ton/ha)

\begin{tabular}{l|c|c|c|c}
\hline \multirow{2}{*}{ Pulse crops } & \multicolumn{4}{c}{ District } \\
\cline { 2 - 5 } & Rajshahi & Natore & Jessore & All \\
\hline Lentil & - & 1.9 & 2.1 & 2.0 \\
Chickpea & 1.6 & 1.5 & - & 1.6 \\
Mungbean & 1.5 & - & 1.8 & 1.7 \\
\hline
\end{tabular}




\section{3 Cost of Cultivation for Selected Pulses}

The estimated total variable cost were Tk 39,493, Tk 34,215 and Tk 39,938 per hectare for lentil, chickpea and mungbean cultivation respectively. These costs shared $56 \%, 52 \%$ and $49 \%$ of the total cost of production respectively. Among the cost items, human labour was the major cost item which shared 32\%, 26\% and $31 \%$ of the total cost respectively in the study areas (Table 3.3). Mechanical power cost accounted for about $6 \%-7 \%$ of the total cost for selected pulse cultivation. Pesticides cost were more for chickpea and mungbean cultivation compared to lentil cultivation but in the case of irrigation, farmers did not apply irrigation for lentil and chickpea cultivation in the study areas. Rental value of land and family supplied labour were considered as fixed cost of production for selected pulses. The cost of these items were Tk 31,233 for lentil cultivation, Tk 32,177 for chickpea cultivation and Tk 41,330 for mungbean cultivation per hectare which accounted for about $44 \%, 48 \%$ and $51 \%$ respectively of the total cost of production (Table 3.3). Total cost of production included variable costs (summation of all cash and non-cash expenses) and fixed costs incurred for selected pulses cultivation. On an average total cost of production were Tk 70,726 for lentil cultivation, Tk 66,392 for chickpea cultivation and Tk 81,268 for mungbean cultivation per hectare. It was observed that the total cost of production of mungbean was highest (Tk 81,268 per hectare) compared to other two pulses due to use of high amount of inputs, especially human labour and chemical fertilizers.

\subsection{Profitability of pulses Crop}

The average marketable yield (which was brought to the market) of lentil was slightly higher $(2.10 \mathrm{t} / \mathrm{ha})$ compared to mungbean $(1.65 \mathrm{t} / \mathrm{ha})$ and chickpea $(1.57$ t/ha). On an average gross return were Tk 145,961/ha for lentil, Tk 108,468 for chickpea and Tk 115,704 for mungbean. Highest gross return was obtained by lentil (Tk 145,961/ha) compared to other two pulses. Gross margin was obtained by deducting total variable cost from gross revenue. Gross margin was $\mathrm{Tk}$ 106,468 per hectare for lentil which was highest in chickpea (Tk 74,252 per hectare) and mungbean (Tk 75,766 per hectare). Net return followed the similar trend like gross return. The net return was Tk 75,235 per hectare for lentil which was highest in chickpea (Tk 42,119 per hectare) and mungbean (Tk 34,434per hectare). The benefit cost ratio (BCR) was also highest for lentil (2.07) compared to other two pulses. On the basis of total cost, the cost of production per kilogram were Tk 34.96 for lentil Tk 42.43 for chickpea and Tk 49.51 for mungbean. On the other hand, variable cost basis calculation showed that the per kilogram production costs were Tk 19.64 for lentil, Tk 22.0 for chickpea and Tk 24.35 for mungbean (Table 3.4). 
Table 3.3. Per hectare costs in producing selected pulses

\begin{tabular}{lccc}
\hline \multirow{2}{*}{ Items } & \multicolumn{3}{c}{ Cost of cultivation (Tk/ha) } \\
\cline { 2 - 4 } Variable cost: & Lentil & Chickpea & Mungbean \\
Hired human labour & $22950(32.45)$ & $17100(25.77)$ & $25350(31.19)$ \\
Mechanical power & $4869(6.88)$ & $4491(6.77)$ & $4603(5.66)$ \\
Chemical Fertilizers: & & & \\
Urea & $520(0.74)$ & $512(0.77)$ & $632(0.78)$ \\
TSP & $2112(2.99)$ & - & $2000(2.46)$ \\
MoP & $624(0.88)$ & - & $855(1.05)$ \\
DAP & - & $2145(3.23)$ & - \\
Boron & - & $780(1.17)$ & - \\
Seed & $6719(9.50)$ & $6890(10.38)$ & $2990(3.68)$ \\
Irrigation & - & - & $1161(1.43)$ \\
Insecticide/Pesticides & $676(0.96)$ & $1409(2.12)$ & $1309(1.61)$ \\
Interest on operating capital & $1025(1.45)$ & $888(1.34)$ & $1038(1.28)$ \\
Total variable costs: & $39,493(55.84)$ & $34,215(51.57)$ & $39,938(49.14)$ \\
Fixed cost: & & & \\
Family Labour & $10650(15.06)$ & $11550(17.41)$ & $19500(23.99)$ \\
Rental value of land & $20583(29.10)$ & $20627(31.02)$ & $21830(26.86)$ \\
Total fixed cost: & $31,233(44.16)$ & $32,177(48.43)$ & $41,330(50.86)$ \\
Total cost & $70,726(100.00)$ & $66,392(100.00)$ & $81,268(100.00)$ \\
\hline
\end{tabular}

Figures in the parenthesis indicate percent of total cost

Table 3.4. Per hectare return in producing lentil in the study areas

\begin{tabular}{l|c|c|c}
\hline \multirow{2}{*}{\multicolumn{1}{c}{ Items }} & \multicolumn{3}{c}{ Return (Tk/ha) } \\
\cline { 2 - 4 } & Lentil & Chickpea & Mungbean \\
\hline Yield (ton/ha) & 2.03 & 1.57 & 1.65 \\
Gross return & 145,961 & 108,468 & 115,704 \\
Gross margin & 106,468 & 74,252 & 75,766 \\
Net return & 75,235 & 42,119 & 34,434 \\
Benefit cost ratio (BCR) & 2.07 & 1.64 & 1.42 \\
Production cost (Tk/kg): & & & \\
Full cost basis & 34.96 & 42.43 & 49.51 \\
Cash cost basis & 19.64 & 22.0 & 24.35 \\
\hline
\end{tabular}

\subsection{Economic Profitability of Pulses Crop}

\subsubsection{Results of the Policy Analysis Matrix for selected pulses crop}

The results of PAM as well as the coefficients of different indicators derived from PAM are discussed sequentially with necessary interpretations. 
Policy Analysis Matrix constructed for selected pulse crops under import parity price is presented in Table 3.5. Table showed that different policy transfer or divergences such as output, tradable input, domestic factor and net policy transfer. Under import parity prices of selected pulse crops, it is evident that revenue transfer (difference between private revenue and social revenue) was negative. This negative value indicated that government policies affect negatively to the pulse producers. The input transfer (differences between private and social price of tradable inputs) was also negative indicating that the domestic pulse producers bought the imported inputs at prices which was less than the world price. It means that pulse producers received input subsidies for selected pulse production. The domestic factor transfer (difference between private and social price) was positive illustrating that the opportunity costs of non-tradable inputs were lower than their market prices. Finally the net profit/net policy transfer (difference between private and social profit) was negative which means that under the existing policy circumstances, the producers earn less profit and enjoy limited scope for minimizing the net policy transfer.

Table 3.5. Policy Analysis Matrix for selected pulse crops

\begin{tabular}{l|l|cc|c}
\hline \multirow{2}{*}{ Items } & \multirow{2}{*}{ Revenue } & \multicolumn{2}{c|}{ Costs (Tk/m.ton) } & \\
\cline { 3 - 4 } & & Tradable inputs & Domestic factors & Profit \\
\hline Private prices & 70,664 & 1886 & 40,221 & 28,567 \\
Social prices & 85,104 & 2994 & 25,040 & 57,070 \\
Divergences & $-14,755$ & -1108 & 15,171 & $-28,503$ \\
\hline
\end{tabular}

Source: Authors own calculation

\subsection{Ratio indicators under import parity}

Important indicators for calculating the level of protection and different ratios such as NPCO, NPCI, EPC, PCR and DRC which were used to measure the effects of policy interventions on the producer incentives and comparative advantage.

\subsubsection{Domestic and border price of selected pulse crops}

The border parity price of selected pulse crops at producer level measured at official exchange rate was mostly higher than the domestic producer price. So, the trends in domestic and border price of selected pulse crops indicated that there is a wide scope to cultivate pulse crops for import substitution in Bangladesh (Table 3.6).

\subsubsection{Nominal Protection Co-efficient on Output (NPCO)}

The study revealed that NPCO values of all selected pulses under import parity were found to be less than one $(<1)$, close to one (Table 3.7). The values close to 
one imply that producers were nearly protected through the existing policy environment. The NPCO values less than one imply that policies do not provide nominal protection for the producers. The NPCO value of mungbean was 0.91 , it meaning that under the market price regime, mungbean producers are getting 9 percent less than the world price.

Table 3.6. Domestic and border price of selected pulse crops at official exchange rate

\begin{tabular}{l|c|c}
\hline Crops & Domestic price $^{\mathrm{a}} \mathrm{Tk} /$ ton & Border price $^{\mathrm{b}} \mathrm{Tk} /$ ton \\
\hline Lentil & 72,740 & 98,359 \\
Chickpea & 68,999 & 79,858 \\
Mungbean & 70,251 & 77,567 \\
\hline
\end{tabular}

Source: Own estimation

Note: a. Harvest time domestic price, b. Economic import parity border price

\subsubsection{Nominal Protection Co-efficient on Input (NPCI)}

For all selected pulse crops, the NPCI values were found to be less than one $(<1)$ under import parity indicating that the government policies were reducing input costs and reducing their average market prices below the world prices (Table 3.7). NPCI values of less than one clearly indicate that the government provides efforts to support these sectors.

\subsubsection{Effective Protection Co-efficient (EPC))}

The study also estimated EPC which is better indicator of effective incentive than the NPC, as it finds the impact of protection on inputs and outputs and depicts the degree of protection according to the value addition process in the production activity. The EPC values under import parity were found to be less than one $(\mathrm{EPC}<1)$ for all selected pulse crops (Table 3.7). But the values of EPC were very close to one indicating that producers were not significantly discouraged by the existing policy regimes.

\subsubsection{Private Cost Ratio (PCR)}

The PCR values found to be less than one $(\mathrm{PCR}<1)$ for all pulse crops under import parity indicating that the commodity system was competitive at the producer level (Table 3.7).

\subsubsection{Comparative Advantage Analysis}

Comparative advantage in the production of a given crop for a particular country is measured by comparing its border price with the social or economic opportunity costs of producing, processing, transporting, handling and marketing an incremental unit of commodity. The results of DRC are presented 
in Table 3.7. DRC indicates whether the domestic economy has a comparative advantage in pulse crops production relative to other countries. The estimates of DRCs for selected pulse crops were observed to be less than unity implying that Bangladesh had comparative advantage in pulse crops production for import substitution.

Table 3.7. Results of the nominal protection coefficient on output (NPCO), Nominal protection coefficient of input (NPCI), effective protection coefficient (EPC), private cost ratio (PCR) and Domestic cost ratio (DRC)

\begin{tabular}{l|c|c|c|c|c}
\hline Crops & NPCO & NPCI & EPC & PCR & DRC \\
\hline Lentil & 0.740 & 0.667 & 0.741 & 0.469 & 0.348 \\
Chickpea & 0.864 & 0.685 & 0.872 & 0.599 & 0.522 \\
Mungbean & 0.911 & 0.548 & 0.927 & 0.690 & 0.640 \\
\hline
\end{tabular}

The above findings based on the indicators of NPCO, NPCI, EPC and PCR conclude that the existing government policy environment tends to protect the interest of the pulse producers in agricultural sector at production level.

\section{Conclusions and Recommendations}

Pulse cultivation is highly remunerative to the respondent farmers in the study areas. The highest cost was estimated for mungbean (Tk 81,268/ha) followed by lentil (Tk 70,726/ha) and chickpea (Tk 66,392/ha). However, the highest net return was estimated for lentil ( $\mathrm{Tk} 75,235 / \mathrm{ha}$ ) followed by chickpea ( $\mathrm{Tk}$ $42,119 / \mathrm{ha}$ ). The highest benefit cost ratio (BCR) was also for lentil followed by chickpea. PAM results under import parity prices of pulse crops showed that revenue transfer was negative indicating the government policies affect negatively to the pulse producer. The input transfer was also negative indicating that pulse producer received input subsidies for pulse production. The domestic factor transfer was positive illustrating that opportunity costs of non-tradable inputs were lower than their market prices. Finally the net profit/net policy was negative which means that under the existing policy circumstances, the producers earn less profit and enjoy limited scope for minimizing the net policy transfer. DRC results indicated that Bangladesh has comparative advantage of producing pulse crops as the estimates of domestic resource cost (DRC) were less than one implied that the production of pulse crops would be highly efficient for import substitution. From the findings of comparative advantage analyses, it is revealed that Bangladesh has comparative advantage of pulse crops production and can produce pulse crops for import substitution. Therefore, research and extension services should be strengthened to introduce modern technologies for higher crop productivity and quality assurance for maintaining competitiveness in the world market should also be considered. 


\section{Reference}

Appleyard, D. R. 1987. - Report on Comparative Advantage, Agricultural Price Commission (APCom Series no 61), Islamabad.

BBS. 1992, 1987, 2004, 2008, 2012, 2015. Bangladesh Bureau of Statistics. MoP, Dhaka.

FAO. 2011. Production Yearbook, Food and Agricultural Organization, Rome, Italy.

Gonzales, L. A., F. Kasryno, N. D. Perez and M. W. Rosegrant. 1993. Economic Incentives and Comparative Advantage in Indonesian Food Crop Production, Research Report 93, International Food Policy Research Institute, Washington D.C.

Masters, W. A. and A. Winter-Nelson. 1995. Measuring the Comparative Advantage of Agricultural Activities: Domestic Resource Costs and the Social Cost-Benefit Ratio. American Journal of Agricultural Economics. 77: 243-50.

Monke, E. A. and S. R. Pearson. 1989. The Policy Analysis Matrix for Agricultural Development, Ithaca NY: Cornell University Press. 
